\title{
AC 2011-1316: THE FRESHMAN ENGINEERING EXPERIENCE: RESULTS FROM A MIXED-METHOD EVALUATION STUDY
}

\section{Jae Hoon Lim, University of North Carolina at Charlotte}

Dr. Jae Hoon Lim is an Assistant Professor of Research Methods at the University of North Carolina at Charlotte and teaches introductory and advanced research method courses in the College of Education. Her research interests include socio-cultural issues in mathematics education and various equity topics in STEM fields. She has served as a lead investigator for multiple international and comparative educational research and evaluation projects. She published twenty-five articles in scholarly and professional journals world-wide and authored seven book or monograph chapters.

\section{Patricia A. Tolley, University of North Carolina, Charlotte} Kimberly Warren, University of North Carolina, Charlotte

Dr. Warren is an Assistant Professor of Civil and Environmental Engineering at UNC Charlotte. She conducts research in the area of geotechnical engineering with a specific interest in earth retaining structures designed with geosysnthtic (polymeric) materials. She conducts large, full-scale field experients that are highly instrumented to monitor and analyze the behaviors of civil engineering structures. In the past few years, Dr. Warren has also recieved funding to conduct engineering education research with the goals of 1) working in a multi-disciplinary team to increase the retention of engineering students at UNC Charlotte and 2) seperately enhancing a core Geotechnical Engineering course by implementing interactive curriculum tools and creating an interactive learning environment in the classroom.

\section{Peter Thomas Tkacik, University of North Carolina, Charlotte}

Dr. Peter Thomas Tkacik is an Assistant Professor at the University of North Carolina at Charlotte with a Motorsports focus. His areas of research are teaching, visual based experimental methods and fluid dynamics. He has advised 6 Graduate Students, 38 under-graduate (UG) seniors, 8 UG summer research experiences, 48 high school summer program kids, and has been the advisor for three UNC Charlotte student race teams. 


\title{
The Freshman Engineering Experience: Results from a Mixed-Method Evaluation Study
}

\begin{abstract}
A mixed-method research design was used to investigate the attitudes, perceptions, and experience of 256 students enrolled in an introduction to engineering course in the Lee College of Engineering at the University of North Carolina at Charlotte (UNC Charlotte) during fall 2009. Major contextual and individual factors were incorporated into the study to evaluate their influence on students' persistence in the major. By the end of the semester, there was a statistically significant difference in students' perceptions of the major and the profession. Although they were more likely to believe that engineers are more concerned with improving the welfare of society than other professions, they were less likely to believe that the future benefits of studying engineering were worth the effort. They also had a less favorable view of engineering professionalism, and they were less likely to be interested in engineering as a career. These results suggest that some freshman students started to re-consider the value of engineering degree during the first semester as they realized the demanding engineering curriculum and high level commitment required of them. However, by the end of the semester, $88 \%$ of the students still liked engineering as a career. The follow-up qualitative data analysis showed different patterns between male and female students' peer relationships and support systems. Furthermore, male and female students also tended to adopt slightly different coping strategies relative to the demanding course workload. While male students were more likely to form a quick social network and to build "learning relationships" with "like-minded" others most female students tended to work alone and exclusively focused on academic work while not seeking more diverse and non-academic social networking opportunities. Each strategy seems to present some positive and negative consequences.
\end{abstract}

\section{Introduction}

During the last two decades, there has been growing consensus among engineering educators and policy makers that the retention and academic success of engineering students is a critical issue that will generate a profound impact upon the nation's economy and prosperity. ${ }^{1}$ According to the American Society of Engineering Education, enrollment in baccalaureate programs increased $14 \%$ between 2000 and 2005, but the number of engineering graduates remained relatively unchanged since 2005 . $^{2}$ The demand for qualified engineering graduates will grow $11 \%$ between 2008 and 2018 based on the most recent U.S. Bureau of Labor Statistics projections. ${ }^{3}$ Therefore, preparing a qualified engineering workforce is a national issue particularly since the scientific and technological leadership of the U.S. has "experienced a gradual erosion" 4 of its position. Considering the critical role played by qualified and competent engineers in today's high-tech industries and technology-driven society, it is not an exaggeration that the task of preparing such a qualified work force has emerged as one of most important tasks for engineering educators.

It is well-known that the field of engineering has long suffered from low retention. ${ }^{5}$ For example, earlier statistics based on the cohort of 1992 -1998 showed that engineering programs in higher education presented one of the lowest retention rates; the proportion of students who completed their science and engineering degree in six years was only $38 \% .^{5}$ More recently, approximately 
one half of all freshmen engineering students who started out in the major ultimately graduated with an engineering degree. ${ }^{1,6,7}$ As a result, both scholars and practitioners have long expressed their concerns about the shortage of graduating engineers as compared to the increasing demand for such a workforce to fuel the nation's economy. ${ }^{8}$ Fortunately, there has been positive change in the last ten years that shows engineering retention rates are more comparable to those of other disciplines. ${ }^{9}$ It is now estimated that about one half of the college students who matriculated in engineering program will earn an engineering degree. ${ }^{10}$ One of the most recent and comprehensive studies conducted by Ohland et al. ${ }^{11}$ reported $57 \%$ of students initially enrolled in engineering remain in the program in their eighth semester, which is the highest retention rate among eight students groups (e.g. Arts and Humanities; Social Sciences; Business; Other STM), examined and compared in the study.

As part of a nation-wide effort to provide accurate information and knowledge-base that are essential to the development of an effective and robust engineering program, numerous research studies were undertaken during the last twenty years. Most of these studies examined the current status of and challenges in the field of engineering education, such as low retention rates, ${ }^{10}$ a declining interest in majoring engineering, ${ }^{12}$ persistent lack of diversity in the engineering student population and the community of engineers in practice, ${ }^{13}$ and relevance and/or effectiveness of current engineering programs to meet fast-changing industrial and societal needs. ${ }^{14,15,16}$ In particular, the freshman year experience was viewed as the most significant factor affecting student retention rate, it elicited great attention from researchers and practitioners. ${ }^{17}$

\section{Purpose of the Study}

This paper presents results from a mixed-method research study that explored the attitudes, perceptions, and experience of students enrolled in an introduction to engineering course at UNC Charlotte during fall 2009. Major contextual and individual factors were incorporated into the study to evaluate their influence on students' perceptions and experiences during their first semester in the major. In particular, the quantitative analysis examined major changes that occurred in students' perceptions using pre- and post-surveys. The follow-up qualitative analysis focused on the subtle differences observed between male and female student's perceptions and their overall social and learning experience. This study is part of a comprehensive, long-term effort to improve freshman engineering retention.

\section{Literature Review}

According to researchers, the freshman year experience appears to be the most significant relative to student retention. ${ }^{17}$ Despite some improvements made in engineering education nationally during the last ten years, only about half of all freshmen who start out in the major ultimately graduate with an engineering degree. ${ }^{1,6,7}$ Seminal research conducted by Astin revealed that: (1) lack of community and majoring in engineering adversely affected students' overall satisfaction with college, (2) academic performance was negatively correlated with majoring in engineering, and (3) the single most influential factor in college student development was the peer group. ${ }^{18}$ The freshman college experience provides rich opportunities for learning and development as students navigate the transition from teen-ager to young adult, dependence to independence, and career exploration to preparation. The greatest opportunities for learning 
and the greatest risk for attrition occur as students separate from family, incorporate into college life, and adjust to their new life emotionally, socially, and academically. ${ }^{19,20,21}$

Tinto $^{22}$ identified seven major causes of student attrition: academic difficulty; adjustment difficulty; uncertain, narrow, or new goals; weak and external commitments; financial inadequacies; lack of social or academic congruence between the individual and the institution; and isolation. He suggested that institutional efforts to retain students must focus on integrating their academic experience with their social experience. This is especially important during the first four to six weeks of college, which is a period of vulnerability and adjustment, when students' experiences can influence their decisions about whether to stay or leave. Students who successfully complete the first semester of college are more likely to return their second semester. $^{23}$

Tinto also identified three principles that are hallmarks of effective retention programs: community, commitment, and education. From the outset, students are integrated into social and academic communities. ${ }^{19}$ Student-student and student-faculty interactions in and out of the classroom are critical elements for enhancing community. Students are provided opportunities to acquire the knowledge and skills necessary for success within their communities. Effective retention programs also demonstrate their commitment to students by proactively striving to enhance their welfare rather than focusing on institutional interests only. Finally, studentcentered institutions are committed to the intellectual and social growth of students; that is, they are committed to their education and not just retention.

\section{Community Building}

The ability to successfully adjust to the emotional, cognitive, and social challenges of living on one's own for the first time, develop new friends and support networks, examine personal values and beliefs, explore various career options, and choose/succeed in a major is dependent on robust self-efficacy. ${ }^{24,25,26,27,28,29,30,31,32,33,34}$ Self-efficacy is the belief in one's ability to organize and execute courses of action to achieve specific outcomes. ${ }^{24}$ The rigor of the engineering curriculum affects self-efficacy appraisals and students' choices about persisting in the major, particularly for female and minority students. ${ }^{1,27,35}$ Attitudes and perceptions also influence career choices. For example, Besterfield-Sacre, Atman, and Shulman found that freshmen who left engineering in good academic standing had lower general impressions of the profession and less confidence in their math, science, and engineering skills than students who remained in the major. ${ }^{36}$

Zhang et al. conducted a study that involved nine engineering institutions, including the site in this study, to investigate the relationship between graduation and six incoming characteristics: Ethnicity, gender, citizenship status, high school GPA, SAT math score, and SAT verbal score. ${ }^{7}$ Only $15 \%$ of the students who started in engineering graduated within the major after four years and approximately half graduated after six years. Overall, all six predictors were significant but their significance, their strength, and the overall variance accounted for by the combination of predictors was dependent upon the institution. The authors remarked that "[i]n trying to predict student success, there is certainly an upper limit on how much of the variation can be predicted from pre-existing factors...the choices students make after matriculation affect student success significantly" (p. 319). The phrase in italics is included in the original quote. 
There is evidence that suggests that a supportive learning environment can greatly influence a student's ability to adapt and succeed especially during the period of transition and vulnerability that is characteristic of the freshman college experience. ${ }^{28,31,37,38}$ Many institutions have implemented academic, extra-curricular, and residential learning communities as a strategy for enhancing students' sense of community, promoting a positive freshman year experience, and improving academic performance and retention. $39,40,41,42,43,44,45,46$

\section{Role of Social Engagement}

Recent studies suggest that pre-collegiate predictors for engineering student retention and success could be different from those for non-stem majors. Veenstra et al. examined the variations in predicting freshman engineering student academic success as compared to three other non-engineering majors (pre-Med, other STEM majors, and non-STEM majors) with the 2004-2005 cohort data from the University of Michigan. ${ }^{47}$ They found that only high schoolrelated factors (high school GPA and school rank) are common factors across different disciplines; other predictors of student academic success, such as study habits, financial aid, and social engagement, were discipline-specific. They found that quantitative skills and the students' reported confidence in their quantitative skills are two unique factors in predicting the academic success of engineering students. Based on their research and extensive review of existing literature, they identified seven pre-collegiate predictors that contributed to the academic success of freshman engineering students: (1) High school academic achievement, (2) Quantitative skills, (3) Study habits, (4) Commitment to career and educational goals, (5) Confidence in quantitative skills, (6) Financial needs, and (7) Family support. ${ }^{48}$ This list excludes commitment to enrolled college and social engagement, which are two factors that have been known to contribute to freshman academic success and retention. ${ }^{49,50}$ Even though Veenstra et al. acknowledged that the construct of "social engagement" is measured in many different ways and it is hard to identify a significant trend in the use of the construct, they concluded that "the significance of social engagement is more evident in the general college research than in the engineering education research." 48

Contrasting research results regarding the importance of "social engagement" in the academic success and retention of freshman engineering students is at least twofold. Empirical investigations that present a significant variation between general education students and engineering students may suggest that engineering students possess a set of unique pre-collegiate characteristics that is different from those of their non-engineering counterparts. ${ }^{47}$ In this case, a new model should be proposed reflecting the unique characteristics of engineering students (e. g, quantitatively-oriented learning dispositions). Additionally, contradictory results from empirical investigations could be based on the inconsistent use of different measures. ${ }^{48}$ Therefore, it can be argued that researchers should provide a clear definition of "social engagement" and develop and use a specific measure in a more consistent manner. Furthermore, it can be argued that engineering students' pattern of social engagement is different from those who decided to major in non-engineering sectors and, therefore, existing measures are not relevant or effective to assess the type of social engagement required or preferred by engineering students. Third, some problems inherent in the current measures of social engagement should be noted as well. For example, Astin' Theory of Involvement ${ }^{51}$ emphasizes the importance of student participation in 
various clubs and voluntary activities on a college campus is an essential part of their integration into the values of the institution. However, actual measures for social engagement used in many empirical studies tend to assess their pre-collegiate social engagement rather than their actual social engagement on their college campus. ${ }^{47}$ Furthermore, individual survey items measuring student "social engagement" have a strong non-academic component (e. g, time spent partying or doing volunteer work). Considering the relatively high academic demand that characterizes engineering programs, this type of non-academic and non-professional social engagement may not be relevant to explaining the type of social engagement required of and preferred by engineering students. In other words, the pattern or characteristics of social engagement among engineering students might be different from those majoring in non-engineering sectors.

Previous studies suggest that some types of social engagement are critical to the academic success and retention of engineering students. In particular, females and underrepresented ethnic minority students seem to value and benefit from various types of social engagement or social relationship. For example, when deciding what to major in, female engineering students were more motivated by encouragement provided by their mentors while male engineering students were more motivated by behavioral aspects of engineering (e.g., I like to build stuff; I like to figure out how things work) as the primary axis of their motivation. ${ }^{52,53}$ In addition, Chachra et al. reported that female engineering students more often participated in both engineering and nonengineering extracurricular activities compared to the males. ${ }^{54}$ Furthermore, female students attached more values to the non-engineering activities at a statistically significant level $(p<0.05)$. Based on this result, they concluded that activities that occurred outside of their engineering classroom might play a more vital role for a female engineering student compared to their male peers.

The literature provides ample evidence about the importance of interpersonal relationships and social engagement in for the success of a female student in a traditionally male dominated field such as mathematics and engineering. Belenky et al.'s seminal work on women's way of knowing offers valuable insight to examine the nature of challenges faced by female students in engineering education. ${ }^{55}$ Belenky and her colleagues explain that women are connected knowers and, therefore, tend to rely on interpersonal relationships and commonality of experience when they approach a new idea or knowledge. ${ }^{55}$ Not surprisingly, scholars in STEM education have reported that a relationship-rich learning context (e.g., group work), in comparison to a separated and individuated learning context, positively influences female students' learning experiences

56,57 and actual learning outcome. ${ }^{58,59}$ Researchers also reported that a high quality and supportive relationship with instructional authority is critical to the intellectual pursuit and perseverance of a female student in a male dominated domain. ${ }^{15,60,61,62}$

\section{Setting}

This ongoing study involved engineering students enrolled in an introductory engineering course, ENGR 1201, at during the fall 2009 semester. ENGR1201 is the first and only engineering course that students take in the fall semester of their freshman year at this institution. The course introduces them to the engineering profession and the various disciplines, basic engineering theory and mathematics, the engineering design process, project planning, cost estimating, teamwork, and oral and written technical communications. Calculus I is a co-requisite and only 
College of Engineering students may enroll in the course in the fall semester. Enrollment is each section is limited to 28 students to facilitate student-student and student-faculty interactions. A teaching assistant (TA) is assigned to each section to serve as a mentor and grader. Students work in small teams to complete three hands-on projects that require them to design, build, and test their solutions. In fall 2009, 357 students enrolled in ENGR 1201.

Selected sections of ENGR 1201 are reserved for students in the College of Engineering residential Freshman Learning Community (FLC). Over 200 students, which represent approximately half of each new freshman engineering cohort, live in the FLC. Onsite academic and professional development programming such as peer mentoring, tutoring, supplemental instruction, chemistry study nights, guest speakers, and site visits to local engineering companies is available to all participants.

\section{Quantitative Data Collection}

The Pittsburgh Freshman Engineering Attitude Survey ${ }^{36}$ was administered in the ENGR 1201 class during the first and last weeks of the fall 2009 semester. Students were notified that participation was voluntarily. The survey included 50 questions designed to measure their attitudes and perceptions on topics ranging from engineering as a career, factors influencing their choice of engineering as a major, confidence in math and science skills, and study habits. Students recorded their responses on bubble sheets using a Likert scale $(1=$ strongly disagree to $5=$ strongly agree). Students were asked to include their identification numbers so that demographic and academic data from the university's data warehouse could be matched to survey responses. A total of 256 identifiable students completed both the pre- and post-surveys which represents a $72 \%$ response rate. An adjusted alpha of .001 was used for the 50 paired sample analyses. SPSS was used to analyze data.

Almost $77 \%$ of the respondents were new freshmen and $11 \%$ were new transfer students admitted in fall 2009. The remaining $12 \%$ were continuing students. Demographics of respondents were consistent with those for undergraduate students in the College of Engineering at this institution: $92 \%$ male, $8 \%$ female, $76 \%$ Caucasian, and $11 \%$ underrepresented minorities. Approximately half (48\%) of the respondents had an SAT Math score of 600 or higher and almost three-fourths (73\%) had a high school GPA of at least 3.5. Approximately $42 \%$ of respondents were FLC participants and $77 \%$ applied for financial aid. By the end of the fall semester, $14 \%$ of the respondents were on academic probation or suspended because they had earned a GPA below 2.0.

\section{Qualtiative Data Collection}

Three types of qualitative datadocument, classroom observation, and interview--were collected for this study in fall 2009 and early spring 2010. The document data included basic demographic information about all ENGR 1201 course instructors, teaching assistants (TA), and students, the course syllabus, instructional materials and lesson plans, major assignment guidelines, and materials used for training the TAs. In fall 2009, eight selected ENGR 1201 lecture and lab sections were observed in full (1 hour 15 minutes per section). The classroon observation was conducted using an observation protocol created to document several key social and cultural 
aspects of the classes. Some key interaction patterns between the instructor and students as well as interactions among students were also recorded during the observation. In-depth interviews with ENGR 1201 instructors, TAs, and students were the central part of the qualitative database.

In fall 2009, seven in-depth individual interviews were conducted with three instructors and four TAs. Each interview was based on a semi-structured interview protocol listing several key questions about what they view as major strengths and weaknesses of the current ENGR 1201 classes and overall engineering program on campus. The instructor interviews took 60 to 90 minutes and TA interviews took about 45 minutes. In total, 48 ENGR 1201 students (38 males and 10 females) were interviewed either in late fall 2009 or early spring 2010 . The student sample consisted of 38 Caucasians, eight Asians including four Middle Eastern students, two African-Americans, three Hispanics, and one Native-American. In total, 39 interviews were conducted as individual interviews while three interviews were conducted as pair interviews that included two students in one interview process. One interivew included three students. Both types of interviews took about 30 to 45 minutes and were also based on a semi-structured interview protocol listing several key questions about their campus and classroom learning experiences. All interviews were audio-recorded and subsequently transcribed verbatim.

Thematic analysis ${ }^{63}$ was conducted to draw major commonalities and differences across various groups of students such as male and female, in-state and out of state students, traditional and non-traditional students, and American and international students. The major characteristics of each participant corrsponding to several key categories were summarized in an Excel file (see Appendix A: Key Categories in Participant Summary). Several interesting key patterns across different groups of students were identified for further, more detailed investigation. A qualiative data analysis software, Atlas- $t i$, was used to create a set of detailed sub-codes for target categories. For example, within "major source of support," several sub-codes such as parents, relatives, peers, college instructors, and high school teachers were created. The sub-codes created in each category were constantly revised throughout the analysis to ensure consitency and accuracy. At the end, a code output table was created showing the consistency and variation of categories and codes across the 48 participants. Based on this code output and participant summary, three of the most salient themes were chosen for presentation in this paper. Therefore, the qualitative findings presented in this paper are primarily based on the analysis of student interview data.

\section{Quantitative Results}

Descriptive statistics were generated for each of the 50 pre- and post- survey items but are not reported due to space limitations. Less than $4 \%$ of the data was missing for any one variable. Means and standard deviations ranged from $1.40-4.75$ and 0.48-1.27, respectively. Values of skewness and kurtosis ranged from $-2.64-2.43$ and $-1.07-8.99$, respectively. Many survey items had non-normal distributions based on skewness and/or kurtosis values $>+/-1$. The $t$ statistic is robust to slight departures from normality, particularly when sample sizes are large, which was the case in this study. However, due to the large number of pairs, which exhibited some level of non-normality, both a parametric $t$ test and a non-parametric Wilcoxon signed rank tests were conducted and compared. Both tests produced the same statistically significant results. Eleven of the 50 paired samples were statistically significant $(p<.001)$ as indicated in Table 1. 
Table 1: Results of Statistically Significant Paired-Samples t Tests (ps $<.0001)$

\begin{tabular}{l|c|c|c|c|c|c|c}
\hline \multicolumn{1}{c|}{ Survey Item } & $\begin{array}{c}\text { Pre } \\
\text { Mean }\end{array}$ & $\begin{array}{c}\text { Post } \\
\text { Mean }\end{array}$ & SD & $\begin{array}{c}\text { CI: } \\
\text { Lower }\end{array}$ & $\begin{array}{c}\text { CI: } \\
\text { Upper }\end{array}$ & $t$ & $d f$ \\
\hline $\begin{array}{l}\text { Engineering is more concerned with } \\
\text { improving the welfare of society than most } \\
\text { other professions. }\end{array}$ & 3.35 & 3.57 & 1.06 & -.35 & -.09 & -3.33 & 253 \\
\hline $\begin{array}{l}\text { Most of my friends that I 'hang out' with } \\
\text { are studying engineering. }\end{array}$ & 3.01 & 3.30 & 1.09 & -.42 & -.15 & -4.14 & 247 \\
\hline $\begin{array}{l}\text { I am confident in engineering. } \\
\text { I am confident in writing. }\end{array}$ & 3.96 & 4.16 & .79 & -.30 & -.11 & -4.09 & 249 \\
\hline $\begin{array}{l}\text { The future benefits of studying engineering } \\
\text { are worth the effort. }\end{array}$ & 4.57 & 4.36 & .82 & .11 & .31 & 4.06 & 255 \\
\hline $\begin{array}{l}\text { Engineering involves finding precise } \\
\text { answers to problems. }\end{array}$ & 4.09 & 3.79 & .96 & .18 & .42 & 4.99 & 252 \\
\hline $\begin{array}{l}\text { I am studying engineering because I enjoy } \\
\text { figuring out how things work. }\end{array}$ & 4.47 & 4.26 & .80 & .11 & .31 & 4.16 & 251 \\
\hline $\begin{array}{l}\text { I like the professionalism that goes with } \\
\text { being an engineer. }\end{array}$ & 4.16 & 3.87 & 1.02 & 17 & .42 & 4.62 & 253 \\
\hline $\begin{array}{l}\text { I enjoy the subjects of math and science the } \\
\text { most. }\end{array}$ & 4.23 & 4.03 & .92 & .09 & .32 & 3.49 & 251 \\
\hline $\begin{array}{l}\text { I am confident in chemistry. } \\
\text { I don't care for this career. }\end{array}$ & 3.60 & 3.06 & 1.07 & .41 & .67 & 7.94 & 246 \\
\hline
\end{tabular}

By the end of the semester, participants were more likely to believe that the engineering profession is more concerned with improving the welfare of society than most other professions. Participants were also more likely to socialize with other engineering majors and were more confident in their engineering and writing skills. On average, fewer students believed that the future benefits of studying engineering were worth the effort and that engineering involves finding precise answers to problems. They were less likely to be studying engineering because they enjoyed figuring out how things work or because they liked the professionalism that goes with being an engineer. They were also less likely to enjoy the subjects of math and science and were less confident in their chemistry skills. The effect size for the latter was moderate and equal to a half of a standard deviation (Cohen's $d=.49$ ). Effect sizes for the other 10 paired samples in Table 1 ranged from $d=.20$ to $d=.33$, which indicates that pre/post mean differences were small (i.e. one-fifth to one-third of a standard deviation). More students also indicated that they did not desire to pursue engineering as a career.

By the end of the semester, $88 \%$ of the participants indicated that they cared for engineering as a career. Consequently, correlation coefficients $(r)$ between this statement and the other 49 postsurvey items were examined to identify which factors may have influenced the students' attitude about engineering as a career choice. Relationships were considered moderate if $r \geq .35$ and strong if $r \geq .65$ and 16 items were found to be significantly and moderately associated with this opinion. As indicated in Table 2, only three of these relationships were positive. 
Table 2: Post-Survey Items Moderately Related to: I Don't Care for This Career

\begin{tabular}{l|c}
\hline \multicolumn{1}{c|}{ Survey Item } & $r^{*}$ \\
\hline The rewards of getting an engineering degree are not worth the effort. & .61 \\
\hline I expect that engineering will be a rewarding career. & -.59 \\
\hline The future benefits of studying engineering are worth the effort. & -.56 \\
\hline The advantages of studying engineering outweigh the disadvantages. & -.54 \\
\hline I expect that studying engineering will be rewarding. & -.51 \\
\hline Engineers are innovative. & -.47 \\
\hline I have no desire to change to another major (ex. Biology, English, chemistry or art). & -.46 \\
\hline I can think of several other majors that would be more rewarding than engineering. & .45 \\
\hline I am studying engineering because I enjoy figuring out how things work. & -.41 \\
\hline From what I know, engineering is boring. & .41 \\
\hline Engineers have contributed greatly to fixing problems in the world. & -.38 \\
\hline I enjoy the subjects of science and mathematics the most. & -.37 \\
\hline Engineering is an occupation that is respected by other people. & -.36 \\
\hline I feel confident in my ability to succeed in engineering. & -.36 \\
\hline I will have no problem finding a job when I have obtained an engineering degree. & -.35 \\
\hline Engineers are creative. & -.35 \\
\hline$* p=.01$
\end{tabular}

In general, students who thought other majors might be more rewarding, who did not believe the rewards of an engineering degree were worth the effort, or who thought engineering was boring were less likely to care for engineering as a career. Conversely, students liked engineering if they perceived engineers as innovative and creative, liked science and math and figuring out how things work, expected that engineering as a major and career would be rewarding, felt the advantages of studying engineering were worth the effort and outweighed the disadvantages, believed that they would be able to find a job upon graduation, were impressed with the respect that goes with being an engineer, understood that engineers contribute to fixing the problems of the world, and were confident in their ability to succeed in engineering.

The students' confidence in their chemistry, calculus, writing, speaking, and computing skills were not significantly related to whether they cared for the career. The lack of significance with chemistry and calculus is especially surprising given the high percentage of engineering majors who typically have to repeat one or both courses at this institution. In comparison, results of the $t$ tests reported in Table 1 indicate that by the end of the semester, students were less confident in their chemistry skills but more confident in their engineering and writing abilities. In fact, the percentage of students indicating that they enjoyed the subjects of math and science the most decreased from $83 \%$ on the pre-survey to $76 \%$ on the post-survey. 
Also of interest is the fact that students whose parents were making them study engineering were more likely to dislike the profession than students whose parents wanted them to study it. This finding suggests that parents who encourage and support their children's decision to pursue engineering may have a greater impact on academic persistence than parents who deny their children the choice of their own major. However, there was a significant albeit weak relationship between these two survey items, which indicates some overlap. In addition, students who indicated that they did not care for engineering tended to believe that other majors contribute as much if not more to improving the world. To a lesser extent, they were also less likely to care for engineering if they were not confident in their engineering, design, and physics skills; if they did not know what an engineer does; and if they did not believe that a degree in engineering would guarantee a job upon graduation.

In summary, results of the quantitative analyses indicate that a myriad of factors affect a students' decision to remain in the major. Although students may have some understanding of what engineering is, what engineers do, and the important role that engineers play in society, differences in personal preferences, self-confidence, commitment, motivation, and external factors such as parental influence, are important and confounding factors that can affect their persistence.

\section{Qualitative Findings}

As shown in the survey results from this study and consistent with other studies conducted by the College of Engineering, qualitative data also suggest that most ENGR 1201 students were highly satisfied with their current program and are motivated to remain in the program. They reported that ENGR 1201 instructors and other faculty members in their respective program provided excellent support and personal connection. In particular, ENGR 1201 students living in the residential FLC were extremely satisfied with the extra-curricular academic and professional development opportunities provided by the FLC. Not surprisingly, these students also developed a solid social and instructional support network among themselves and benefited from the network by gaining informal instructional support to survive demanding prerequisite courses. ENGR 1201 instructors and TAs expressed concern about successfully maintaining pedagogical consistency across the 13 sections of ENGR 1201 taught in fall 2009, and the difficulty in developing personal relationships with a growing number of students enrolling in the courses. To the contrary, the ENGR 1201 students interviewed indicated that they were satisfied with the support available to them. For example, Max found all intimidating warnings about uncaring college professors at his high school were not really true in his experience on campus. Jimmy's evaluation provided below is a typical response observed in almost all student interviewees.

Interviewer: What kind of expectation did you have about coming to college here? Not just Engineering part but the whole experience. What were you thinking it might be like? Max: Um... well, I thought it was going to be really hard. And, I would have to study a lot. And I mean... Before my teachers in high school would say like "You professors, they don't care what your excuse is. It's just they don't really care 'cause they have so many students". But when I came here... I don't know. I think it was... Most of that was just an illusion, I guess. 'Cause, the professors really do care. 
Interviewer: What do you think is the easiest part of the program experience?

Jimmy: Um... I say getting, getting help when you need it, if you need it. I know [that] my T.A.'s, I mean he's been real helpful. I've gone to him about a lot of things. Just you know. It could be something important or just a random question. He's usually, especially through e-mail, he'll- he responds real quick. Uh... same thing with my professor, Mrs. Bolick. She is always, you know, right on top of everything. Um... my advisor... he's also an Engineering professor. I've been able to go to him... about certain things. And, everybody's real helpful.

Being asked to identify a few major challenges that they faced during the first semester on campus students listed school workload and time management as two major challenges. In particular, chemistry class was frequently referred to as the most difficult class by many students. Five male students listed the ENGR 1201 class as a challenging class but no female students identified the class as a challenge. Instead, four female students reported a significant challenge in their social adjustment in college life including the engineering classes. Three students' quotes listed below provide a snapshot of what many students perceived as the hardest challenge on campus during the first semester.

Interviewer: What do you find is the easier part of Engineering program?

Chad: The easier part of engineering program. I'd say the... the work itself is not that hard. It just takes up a lot of time. And, like the math kind of stuff that they do is really easy. So the hard part is just the amount of work and making sure you get it done by the deadline.

Interviewer: What do you find the hardest part of your program experience? Lance: Um... making sure that I make time for all the miscellaneous kind of work that they give me, that doesn't really seem to matter a lot. But, [it] still has quite a lot of weight towards my grade. Especially when all the other students are like, "Oh, it doesn't matter. It's kind of miscellaneous. And, I don't do it". So, it's a little harder to make time myself.

Interviewer: [beside] the Chemistry class, was there any other challenge that you had? Scott: Time management. Interviewer: Okay.

Scott: Definitely going from high school to college, there's [an assumption that] you are independent. No one's there. Your teachers aren't gonna fall off of you and say, "You need to make sure you have this done by this time, or you need to have it submitted online". You have to look ahead of time and be on top of it.

Despite many common threads found across different groups of students (e.g., male and female, in-state and out of state students, American and international students) such as understanding the demanding work level required in their major, there were some interesting differences gleaned from the qualitative dataset. In particular, the qualitative analysis showed some contrasting patterns between male and female peer relationships and support systems. In general, students listed Family, Professional Learning Community (PLC), Friends, and Professor/teachers as four main sources of their academic and emotional support. Both male and female students referred to 
Family most frequently (25 out of 47), yet a higher proportion of female students (80\%) identified their family as their main source of support, as opposed to male students (45\%). Male students tended to show multiple sources of support including family, PLC, and friends. While almost all Caucasian male students developed a new peer relationship and support system during the semester, the majority of female students listed their family as their primary support system. Only four female students mentioned their newly-found friends on campus as an important source of support. As a result, $70 \%$ of the female students were evaluated as in need of making progress in their peer relationship at the time of interview. Only one of 39 male students showed the same level of challenges in making social relationship and gaining support from his peers. Not surprisingly, results of the Pittsburgh survey show a quite large mean difference (male $M=$ 3.33 vs. female $M=2.90$ ) in the post survey item measuring male and female student peer relationships. Males made a significant improvement in their peer relationships between pre- and post-surveys $(p<.01)$. Female peer relationships remained unchanged during the same period. In general, female students exhibited a more independent work disposition, had little prior relationships to utilize to develop new relationships, and were less active in various social networking activities as compared to their male counterparts. Two quotes listed below show that both Aaron (a traditional engineering student) and Travis (a non-traditional student) found it easy to make friends and formed a productive relationship that contributed to their successful adjustment during the semester. Aaron who delightfully mentioned his grandfather who is an engineer and had possibly influenced his decision to pursue an engineering degree weighed more on his friends' support when the interviewer asked about his primary source of support. Travis, a non-traditional engineering student, found himself receiving respect from other younger students and still being able to find "like-minded" others with whom he could establish "study relationships."

Interviewer: What's the easier part of college life?

Aaron: Um... making friends, turning things in on time... go- uh, not really going to class 'cause you have to wake up. (Laughed. Aaron's narrative about his grandfather who is an engineer is omitted here)

Interviewer: So tell me a little bit about the important people in your life. Like, your family or your friends?

Aaron: Well, my friends are most important to me 'cause... they're like my structure. They help me stand up. They help me get through things that I need to get through.

Interviewer: Tell me about a little bit about your social relationship with other students. Travis: Okay. Well, I mean I've gotten along well with most everybody. A lot of the younger students, I know, have noticed, I guess, because of being older, and as hard as I work, they kind of respect that. Like, they happen to ask questions and for advice for help and stuff. And, but, most of the friendships I've kind of formed were the one who was a little bit older. So, we could relate on some of the stuff that... Some [students]...they don't quite remember. 'Cause, they might have been too young. Some of the younger ones, though... [I] kind of noticed that they were more mature and responsible and acted older than their age, I guess. It made me feel more comfortable. 'Cause, I'm used to people who are acting on a higher maturity level and stuff. So just like at work, you tend to make better relationships with people who are a little bit more 
like-minded with you and people you don't think are too irresponsible. And it's kind of plans out the same way. So, those... I mean, they've come out pretty good. We're mostly like study relationships and stuff like that.

In contrast, the female students' interview data presented evidence that they experienced various challenges in making social and cultural adjustment on campus. In particular, four female students reported a significant challenge in their social adjustment in college life and/or in various communities of engineering students on campus. For example, Kristine and Melissa listed below expressed a sense of sacrifice and isolation in their college experience. Kristine, a traditional freshman student, found it hard to stay away from her home and family members and conceptualized her college life as "sacrifice." Melissa, a transfer student, said "especially being a transfer student.... I"ve just kind of stuck with my (her) roommate's friends" feeling "there was something missing" in an engineering fraternity.

Interviewer: What do you find to be the hardest part (in your college experience)? Kristine: Hardest part, um... I mean school in self is hard. It was harder leaving home [and] coming down here by myself.

Interviewer: Yeah. I bet. With... (your) brothers, and-

Kristine: Yeah.

Interviewer: Well, how do you deal with the challenge of leaving home and being so far away?

Kristine: Just knowing that hopefully in four years I'll graduate with a degree in engineering, and will be doing what I want to do. So [this is]... sacrifices.

Melissa: Me, I think like, in terms of meeting people and the Engineering... The Engineering program itself, it doesn't really... If you just go to class, you're not going to really meet people that... You- you're not guaranteed to meet people that you'll want to hang out with.

Interviewer: Right.

Melissa: I went to the Theta Tau Formal with one of my friend who's in the fraternity.

And, that was kind of cool. But, I still- I mean... you know, it's an Engineering fraternity.

Interviewer: Yeah.

Melissa: And, so I met a couple of people. But, it was still like... you know, it was like there was something missing to it. You know? So, I don't know. It's- it's kind of, I still can't put my finger on it.

Interestingly, the female interviewees in this study exhibited less interest in participating in nonacademic social activities. They showed a more independent work attitude and goal-oriented peer relationships. Below, three female students, Amanda, Jessica, and Marie, reflect such tendency. Interestingly, these three female students, all exhibiting an independent work disposition and goal-oriented peer-relationship, described their choice quite differently from one another. Amanda described her independent work habit and limited social involvement as the consequence of her natural disposition. Marie rationalized that her focus on goal-oriented relationship benefiting her professional development and stayed away from other purely 
socializing activities. Jessica framed her limited social involvement as an ethical standard that she had to subscribe to in order to succeed in the highly demanding field of her study.

Amanda: Like, I'm talkative... but, I value my alone time. Like, you know, when I'm finished with classes or whatever, I'm fine to just go back to my room and kind of like shut myself off. I'm... I'm perfectly fine with that. And that's how I was in school. My friends always felt like I didn't want to do anything with them or go out. But, it was just... I was a homebody and I was fine entertaining myself. (omitted some conversation about her family life and her being only child in her household) Even when my cousins were around, I was so used to entertaining my own self and doing things by myself a lot of times. So I don't know. I just got so used to it and... it doesn't seem wrong to be that way.

Marie: Like with Theta Tau, some people see it in Fraternities and Sororities, they did support groups and they want to be social. I don't want that. I want it as "it will like look good on my resume". I want it as, "it's [an] association and a society that will help me become better person and a better, you know, employee and, [I] will be better in the engineering field". And, yeah, these guys have gone through the classes that I have gone through. And, they will help me. So, they will be somebody I can turn to and ask for advice. But, I look at it as more... I guess I take little bits and pieces and then just leave me alone. And Andy is getting on to me [asking] about "You don't really go to this. You don't do this." Cause, like regional's was last weekend. I didn't go [there]. I had other prior commitments. But, even if I didn't [have other prior commitments] I don't think I would go. I understand it creates bonding between the members and stuff. And I understand they all have fun. But I will go do the community service. I will go to the meetings. I will go to all [of] that. But, I have no interest in going and playing Pledge Olympics. I have no idea or no interest in going to trivia contests, you know? So I think I just kind of... it's like either you like me and you want me to be part, or you don't. It's either or. I'm not gonna kiss your butt. I'm not gonna sit and idolize you. But, I will respect you, and I will show up, and I will do the job.

Jessica: If you're gonna be an Engineer or major in Engineering, something hard, like, you can't have the same...you're not gonna have like the same... you shouldn't have the same expectations as like other people [do] because, you're not gonna have as much free time. Like you know, you can't like... (sighed) You just got to manage your time more like wiser than others. Because, other people that I know have different majors, they have so much free time. Like you just shouldn't have free time. Like, you just shouldn't. Everything should be on a schedule. That's gonna be your life. You should just prepare for it and ... like it. (laugh)

\section{Discussion}

Fall 2009 was the first time that the Pittsburgh Freshman Engineering Attitude Survey was used in the Lee College at UNC Charlotte. Results of the quantitative analyses indicate that a myriad of factors affect a students' decision to remain in the major. Although students may have some understanding of what engineering is, what engineers do, and the important role that engineers 
play in society, differences in personal preferences, self-confidence, commitment, motivation, and external factors such as parental influence, are important and confounding factors that can affect their persistence.

ENGR 1201 also appears to be influencing a student's decision, both positively and negatively, about a career in engineering. The course is rigorous in terms of the quantity and scope of assignments designed to introduce students to engineering practice. There is a heavy emphasis on technical writing, teamwork, and global, societal, and contemporary issues related to the profession. Students learn that the engineering design process is open-ended, i.e. there is often more than one right answer. They are given multiple opportunities to apply their understanding of engineering concepts related to beam theory and circuit theory and demonstrate their proficiency in engineering mathematics. The changes in attitudes and perceptions over the course of the semester are evidenced by differences in students' responses to the survey items. Collectively, these findings suggest that ENGR 1201 is accomplishing the intended purpose, i.e. to help students determine if engineering is right for them. By the end of the semester, $88 \%$ of the students agreed or totally agreed (ratings of 4 and 5) that they cared for a career in engineering. This finding is consistent with previous course surveys that indicate that $85-90 \%$ of ENGR 1201 students intend to continue pursuing their College of Engineering major.

Assessment of student learning consistently reveals that students struggle with the engineering mathematics required in ENGR 1201. Written comments on end-of-semester teaching evaluations indicate that students perceive the workload to be much greater than that required in their other courses and certainly worthy of more than two hours of academic credit. The selfreported amount of time that they spend studying for all of their courses is clearly much less than is recommended for success in the engineering curriculum. Historically, about $15-20 \%$ of the students who take ENGR1201 in the fall semester typically withdraw from the course or earn a final grade of $\mathrm{D}$ or $\mathrm{F}$. A grade of $\mathrm{C}$ or better is required to progress in the engineering curriculum.

In this study, cumulative GPA was positively and moderately correlated at the .01 level with students' confidence in their calculus skills and their confidence in their study habits or routine. Students' belief that they need to spend more time studying was negatively and moderately correlated with academic performance. The latter suggests that students who did not study as much as they thought they should have earned lower GPAs. This finding can also be related to ENGR 1201 since students are taught academic success strategies in this course. They are told that they should study three hours for every hour in class. A TA is assigned to each section of 28 students to serve as grader, coach, and project manager. In fall 2009, there were 18 TAs available to help students during "learning labs" that were held Monday through Thursday throughout the day. Students were also provided with a myriad of academic support services for calculus, chemistry, and physics. Unfortunately, most did not take advantage of these support services. This realization is also reflected in students' belief that they are not guaranteed a job if they earn an engineering degree. From the time they attend summer orientation, students are told that a GPA of 3.0 or higher is desired by many employers. Those who graduate with lower GPAs may not enjoy the quantity and quality of job offers compared to their higher performing peers.

Qualitative findings from this study provide several interesting points for scholarly discussion. First, this study confirms that the freshman year is an important transition time when students 
start to understand a different learning context on the college campus and align their expectations with the realities of college life, high demands of engineering curriculum, and the rigorous work required of all engineering students to be successful. In general, participants found that college courses are much harder than their high school classes and, therefore, they must increase their commitment level and develop effective time management skills to survive several of the core prerequisite courses that serve as "weed-out" courses. Even though almost all freshmen knew engineering was not going to be an easy major, this newly found level of demand and challenges seemed to be more than what they had initially anticipated. As a result, both surveys and interview data show that participants experienced some adversity in meeting the demanding requirements. It is highly likely that their realization of the demanding engineering curriculum caused them to re-consider the value of their chosen degree/career in comparison to the necessary commitment. Declining patterns in several survey items measuring students' perceived value of studying engineering may reflect this new realization. This result is consistent with other studies reporting that engineering students hope to have some balance in their college lives by having an opportunity to explore other areas of personal interests that goes beyond engineering studies. ${ }^{64,65}$ In any case, it should be noted that there is a clear gap between freshman students' initial expectation for their workload as engineering students and a common workload expectation embedded in college classes. Beginning in fall 2010, ENGR 1201 instructors and freshman academic advisors began a coordinated campaign to more clearly communicate expectations to the students. Their efforts will include sharing the retention and graduation rates in addition to the percentage of students who successfully complete chemistry, physics, and calculus. Future research will include an investigation of differences between the 2009 and 2010 cohorts.

It is also very important to point out that male and female students in our study showed slightly different coping strategies relative to the demanding course workload. In general, male students tended to form a quick social network and adopt a "Play and Study Together" approach. In contrast, most participating female students tend to work alone and exclusively focus on academic work while not seeking more diverse and non-academic social networking opportunities. This is very likely due to the low representation of females in the major. Each strategy seems to present some positive and negative consequences. For example, female students who exclusively focused on academic work and chose to work independently tend to do well in their academic performance, but they also reported more stress and feelings of isolation and self-doubt. Male students who were within a strong social network with other male students easily found some support to compensate for their weaknesses. They also tended to preserve their confidence and engineering identity when their grades were lower than they expected. This finding resonates with a similar point made in a Center for the Advancement of Engineering Education (CAEE) report indicating that female students reported a greater curricular overload than males. ${ }^{53}$ Like other previous studies, female students in this study also reported their strong desire to do well and a need to prove themselves to be respected by their male classmates. ${ }^{66,67}$ However, it is also noteworthy that the majority of female participants in this study tend to be introverted, independent, and goal-oriented. Therefore, their exclusive focus on academic work and less involvement in non-academic social activities may be a natural choice for them. This particular finding differs from a previous study that reported a higher involvement of female engineering students in both academic and non-academic activities ${ }^{54}$ and warrants further 
investigation. Consistent with other research, this study found that female students tend to rely on support provided by parents and mentors. ${ }^{53,68}$

Based on the findings from this study, there is a need for a more in-depth investigation regarding the unique characteristics of different student groups (including female and minority students)

majoring in engineering across diverse institutions. According to Veenstra et al. ${ }^{48}$ a proper retention model for engineering students may be different from that for non-engineering students. Therefore the type of social engagement and support strategies for engineering students who choose to major in engineering might be different from those effective with other students in non-STEM sectors. Different types of social engagement should be examined more thoroughly in order to identify a relevant type of social engagement that has a significant impact on engineering students' academic success and professional development. At the same time, variations across different groups of students (e.g., male and female, majority and minority students) within engineering should be considered. Considering that female engineering students tend to rely more on hierarchical relationships and support (e.g., mentors and parents) than horizontal peer support, different strategies and recommendations can be provided to male and female engineering students. This study suggests that male students benefit from their preexisting social network to build their new peer network during the first semester, female students tend to start their first semester relatively isolated and have to depend on support from their families and previous or current mentors (high school teachers and college instructors).

\section{Conclusion}

A mixed-method research design was used to investigate the attitudes, perceptions, and experience of 256 students enrolled in an introduction to engineering course during fall 2009. Major contextual and individual factors were incorporated into the study to evaluate their influence on students' persistence in the major.

By the end of the semester, there was a statistically significant difference in students' perceptions of the major and the profession. Although they were more likely to believe that engineers are more concerned with improving the welfare of society than other professions, they were less likely to believe that the future benefits of studying engineering were worth the effort. They also had a less favorable view of engineering professionalism, and they were less likely to be interested in engineering as a career. These results suggest that some freshman students started to re-consider the value of engineering degree during the first semester as they realized the demanding engineering curriculum and high level commitment required of them. However, by the end of the semester, $88 \%$ of the students still liked engineering as a career. They also expressed more confidence in their engineering and writing abilities and were also more likely to have friends that were studying engineering at the end of the semester.

The follow-up qualitative data analysis showed some contrasting patterns between male and female students' peer relationships and support systems. While almost all Caucasian male students developed a new peer relationship and support system with each other during the semester, the majority of female students listed their family as their primary support system. Male and female students in our study also showed slightly different coping strategies relative to the demanding course workload. In general, male students were more likely to form a quick 
social network and to build "learning relationships" with other "like-minded" students. In contrast, most female students tended to work alone and exclusively focused on academic work while not seeking more diverse and non-academic social networking opportunities. This is very likely due to the low representation of females in the major and less opportunities to extend their social network with other female students in the program. Each coping strategy seems to present some positive and negative consequences. Female students who exclusively focused on academic work and chose to work independently tend to do well in their academic performance, but they also reported more stress and feelings of isolation and self-doubt. Male students who were within a strong social network with other male students easily found some support to compensate for their weaknesses. They also tended to preserve their confidence and engineering identity when their grades were lower than they expected.

In summary, this study is part of a larger, on-going research project designed to increase the retention rates of the engineering students within the Lee College of Engineering at UNC Charlotte. Findings reveal that the curriculum, learning environment, and support networks are critical components in shaping students' attitudes, perceptions, and experiences, all of which influence their decision to remain in the major. Collectively, this knowledge is valuable for designing a robust and holistic freshman year experience that facilitates a successful transition into college and success in the major. 


\section{References}

1. Seymour, E., \& Hewitt, N. (1997). Talking about leaving: Why undergraduates leave the sciences. Boulder, CO: Westview Press.

2. Gibbons, M. (n.d.) Engineering by the numbers. Retrieved December 17, 2010 from http://www.asee.org/papersand-publications/publications/college-profiles/2009-profile-engineering-statistics.pdf.

3. U.S. Bureau of Labor Statistics. Occupational outlook handbook, 2010-11 edition. Retrieved December 17, 2010 from http://www.bls.gov/oco/ocos027.htm\#outlook.

4. National Science Foundation. (2010). Science and engineering indicators: 2010. Retrieved December 17, 2010 from http://www.nsf.gov/statistics/seind10/c0/c0s1.htm.

5. National Science Foundation (2002). Science and engineering indicators: 2002. Retrieved January 10, 2011 from http://www.nsf.gov/statistics/seind02/c2/c2s2.htm\#retention

6. Astin, A. \& Astin, H. (1992). Undergraduate science education: The impact of different college environments on the educational pipeline of the sciences. Final report. (University of California, Los Angeles Higher Education Research Institute ED 362404). Washington, DC: National Science Foundation.

7. Zhang, G., Anderson, T., Ohland, M., \& Thorndyke, B. (2004). Identifying factors influencing engineering student graduation: A longitudinal and cross-institutional study. Journal of Engineering Education, 93(4), 313-320.

8. French, B. F., Immekus, J. C., \& Oakes, W. (2003, November). A structural model of engineering student success and persistence. Proceedings of the 33rd ASEE/IEEE Annual Frontiers in Education Conference. Boulder, $\mathrm{CO}$.

9. National Science Foundation (2008). Science and engineering indicators: 2008. Retrieved January 10, 2011 from http://www.nsf.gov/statistics/seind08/pdfstart.htm

10. Burtner, J. (2005). The use of discriminant analysis to investigate the influence of non-cognitive factors on engineering school persistence. Journal of Engineering Education, 94, 335-339.

11. Ohland, M. W., Sheppard, S. D., Lightenstein, G., Eris, O., Chachra, D., \& Layton, R. A. (2008). Persistence, engagement, and migration in engineering programs. Journal of Engineering Education, 97(3), 259-278.

12. Melsa, J. L. (2007). The winds of change. ASEE Banquet Keynote Speech.

13. Chubin, D. E., May, G. S., \& Babeo, E. (2005). Diversifying the engineering workforce. Journal of Engineering Education, 94(1), 73-86.

14. Lattuca, L, R., Terenzini, P. T., Volkwein, J. F., \& Peterson. G. (2006).The changing face of engineering education. The bridge: Linking engineering and society, 36(2), 5-13.

15. Lattuca, L. R., Terenzini, P/ T., \& Volkwein. J. F. (2006). Engineering change: A study of the impact of EC2000. Final Report. Baltimore, MD:ABET.

16. National Academy of Engineering. (2004). The engineer of 2020: Visions of engineering in the next century. Washington, DC: National Academies Press.

17. Tinto, V. (1999). Taking retention seriously: Rethinking the first year of college. NACADA Journal, 19(2), 5-9.

18. Astin, A. (1993). What matters in college: Four critical years revisited. San Francisco, CA: Josey-Bass.

19. Tinto, V. (1987). Leaving college. Chicago: University of Chicago Press.

20. Tinto, V. (1990). Principles of effective retention. Journal of the Experience, 2(1), 35-48.

21. Tinto, V. \& Goodsell, A. (1993). Freshman interest groups and the first year experience: Constructing student communities in a large university (National Center on Postsecondary Teaching, Learning, and Assessment ED 358778). Washington, DC: Office of Educational Research and Improvement.

22. Tinto, V. (1996). Restructuring the first year of college. Planning for Higher Education, 25(1), 1-6.

23. Elkins, S., Braxton, J., \& James, G. (2000). Tinto's separation stage and its influence on first-semester college student persistence. Research in Higher Education, 41(2), 251-268.

24. Bandura, A. (1986). Social foundations of thought and action: A social cognitive theory. Englewood Cliffs, NJ: Prentice Hall.

25. Betz, N. \& Hackett, G. (1987). Concept of agency in educational and career development. Journal of Counseling Psychology, 34(3), 299-308.

26. Brown, S., Lent, R., \& Larkin, K. (1989). Self-efficacy as a moderator of scholastic aptitude - academic performance relationships. Journal of Vocational Behavior, 35, 64-75.

27. Hackett, G. (1995). Self-efficacy in career choice and development. In A. Bandura (Ed.), Self-efficacy in changing societies (pp. 232-258). New York: Cambridge University Press. 
28. Hackett, G., Betz, N., Casas, J., \& Rocha-Sigh, I. (1992). Gender, ethnicity, and social cognitive factors predicting the academic achievement of students in engineering. Journal of Counseling Psychology, 39(4), 527-538.

29. Lent, R. Brown, S. \& Larkin, K. (1986). Self-efficacy in the prediction of academic performance and perceived career options. Journal of Counseling Psychology, 33(3), 265-269.

30. Lent, R., Brown, S. \& Larkin, K. (1987). Comparison of three theoretically derived variables in predicting career and academic behavior: Self-efficacy, interest congruence, and consequence thinking. Journal of Counseling Psychology, 34(3), 293-298.

31. Lent, R., Brown, S., Sheu, H., Schmidt, J., Brenner, B., Gloster, C., et al. (2003). Relation of context supports and barriers to choice behavior in engineering majors: Test of alternative social cognitive models. Journal of Counseling Psychology, 50(4), 458-465.

32. Multon, K., Brown, S., \& Lent, R. (1991). Relation of self-efficacy beliefs to academic outcomes: A metaanalytic investigation. Journal of Counseling Psychology, 38(1), 30-38.

33. Nauta, M. \& Epperson, D. (2003). A longitudinal examination of the social-cognitive model applied to high school girls' choices of nontraditional college majors and aspirations. Journal of Counseling Psychology, 50(4), 448-457.

34. Zimmerman, B. (1995). Self-efficacy and educational development. In A. Bandura (Ed.), Self-efficacy in changing societies (pp. 202-231). New York: Cambridge University Press.

35. Goodman Research Group, Inc. (2002). A comprehensive evaluation of women in engineering programs. Retrieved October 8, 2007 from http://www.grginc.com/.

36. Besterfield-Sacre, M., Atman, C., \& Shuman, L. (1997). Characteristics of freshman engineering students: Models for determining student attrition in engineering. Journal of Engineering Education, 86(2), 139-149.

37. Bandura, A. (Ed.). (1995). Self-efficacy in changing societies. New York: Cambridge University Press.

38. Brown, S., Lent, R., Alpert, D., Hunt, G., \& Brady, T. (1988). Perceived social support among college students: Factor structure of the Social Support Inventory. Journal of Counseling Psychology, 35(3), 472-478.

39. Brown, M. \& Minnick, K. (2005). The unnecessary tension between learning communities and intellectual growth. College Student Journal, 39(4), 775-783.

40. James, P., Bruch, P., \& Jehangir, R. (2006). Ideas in practice: Building bridges in a multicultural learning community. Journal of Developmental Education, 29(3), 10-18.

41. Johnson, J. \& Romanoff, S. (1999). Higher education residential learning communities: What are the implications for student success?. College Student Journal, 33(3), 385-399.

42. Moller, L., Huett, J., Holder, D., Young, J., Harvey, D., \& Godshalk, V. (2005). Examining the impact of learning communities on motivation. The Quarterly Review of Distance Education, 6(2), 137-143.

43. Pike, G. (1997). The effects of residential learning communities on students' educational experiences and learning outcomes during the first year of college. Proceedings of the Association for the Study of Higher Education, Albuquerque, NM.

44. Pike, G., Schroeder, C. \& Berry, T. (1997). Enhancing the educational impact of residence halls: The relationship between residential learning communities and first-year college experiences and persistence. Journal of College Student Development, 38(6), 609-621.

45. Tinto, V. (2000). What have we learning about the impact of learning communities on students? Assessment Update: Progress, Trends, and Practices in Higher Education, 12(2), 1-3.

46. Zhao, C. \& Kuh, G. (2004). Adding value: Learning communities and student engagement. Research in Higher Education, 45(2), 115-138.

47. Veenstra, C. P., Dey, E. L., \& Herrin, G. D. (2008). Is modeling of freshman engineering success different from modeling of non-engineering success? Journal of Engineering Education, 97(3), 467-479. .

48. Veenstra, C. P., Dey, E. L., \& Herrin, G. D. (2009). A model for freshman engineering retention. Advances in Engineering Education, 1(3), 1-33.

49. Lotkowski, V.A., Robbins, S. B., \& Noeth. R. J. (2004) "The role of academic and non-academic factors in improving college retention.” ACT, Inc., 2004. Astin, A. W. (1984). Student Involvement: A developmental theory for higher education. Journal of College Student Personnel, 25, 297-308. http://www.act.org/research/policymakers/pdf/college_retention.pdf

50. Robbins, S.B., Lauver, K., Le, H., Davis, D., Langley, R., \&Carlstrom, A. (2004). "Do psychosocial and study skill factors predict college outcomes?: A meta-analysis." Psychological Bulletin, 130, 261-88.

51. Astin, A. W. (1984). Student involvement: A developmental theory for higher education, Journal of College Student Personnel, 25, 297-308. 
52. Kilgore, D., Debbie, C., Atman, C. J., Yasuhara, K. \& Morozov, A. (2009, April). Driven by passion, curiosity, engagement, and dreams. Findings from the Academic Pathways Study on undergraduates ' motivations to study engineering. Presented at the American Educational Research Association. San Diego, CA.

54. Chachra, D., Chen, H. L., Kilgore, D., \& Sheppard, S. D. (2009, October). Outside the classroom: Gender differences in extracurricular activities of engineering students. Proceedings of the 39th ASEE/IEEE Annual Frontiers in Education Conference, San Antonio, TX.

55. Belenky, M. F., Clinchy, B. M., Golberger, N. R., \& Tarule, J. M. (1997). Women's way of knowing; The development of self, voice, and mind. New York: Basic Books.

56. Crosnoe, R., Riegle-Brumb, C., Field, S., \& Frank, K. (2008). Peer group contexts of girls' and boys' academic experiences. Child Development, 79(1), 139-155.

57. Fennema, E., \& Peterson, P. L (1985). Autonomous learning behavior: A possible explanation of gender-related differences in classroom interactions. In L. C. Wilkerson \& C. B. Marrett (Eds.). Gender-related differences in classroom interaction (pp.17-35). New York: Academic.

58. Boaler, J. (1998). Open and closed mathematics: Student experiences and understandings. Journal for Research in Mathematics Education, 29, 41-62.

59. Boaler, J. (2002). Experiencing school mathematics: Traditional and reform approaches to teaching and their impact on student learning, Philadelphia, PA: Lawrence Erlbaum Associates.

60. Herzig, A. H. (2002). Where have all the students gone? Participation of doctoral students in authentic mathematical activity as a necessary condition for persistence toward the Ph.D. Educational Studies in Mathematics, 50(2), 177-212.

61. Herzig, A. (2004). Slaughtering this beautiful math: Graduate women choosing and leaving mathematics, Gender and Education, 16(3), 379-395.

62. Moody, V. (2004). Sociocultural orientations and the mathematical success of African American students. The Journal of Educational Research, 97, 135-146.

63. Ezzy, D. (2002). Qualitative analysis: Practice and innovation. London: Routledge.

64. Stevens, R., O‘Connor, K., \& Garrison. L. H. (2005, June). Engineering student identities in the navigation of the undergraduate curriculum. Proceedings of the American Society for Engineering Education Annual Conference, Portland, OR.

65. Loshbaugh, H. G., Hoeglund, T. J., Streveler, R. A., \& Breaux, K. (2006, June). Engineering school, life balance, and the student experience. Proceedings of the American Society for Engineering Education Annual Conference, Chicago, IL.

66. Garrison, L., Stevens, R., Sabin, P., \& Jocuns, A. (2007, June). Cultural models of the admission process in engineering: Views on the role of gender, women in engineering poster session. Proceedings of the American Society for Engineering Education Annual Conference, Honolulu, HI.

67. Garrison, L. Stevens, R., \& Jocuns, A. (2008, June). Gender, institutional structure and learning in an engineering college. Proceeding of the Eighth International Conference for the Learning Sciences - ICLS 2008, Utrecht, The Netherlands. (pp.1-265 to 1-272).

68. Assessing Women in Engineering. (2005). Family influence. AWE research overviews. Retrieved January 10, 2011 from http://www.aweonline.org.'s 
Appendix A: Table 1-1: Results of Pair Sample t Tests

\begin{tabular}{|c|c|c|c|c|c|c|c|}
\hline Paired Questions & Mean Diff & $S D$ & $\begin{array}{c}\text { CI: } \\
\text { Lower }\end{array}$ & $\begin{array}{c}\text { CI: } \\
\text { Upper }\end{array}$ & $t$ & $d f$ & $p$ \\
\hline PREQ1 - POSTQ1 & .148 & .742 & .057 & .240 & 3.201 & 255 & .0015 \\
\hline PREQ2 - POSTQ2 & .098 & .930 & -.017 & .212 & 1.680 & 255 & .0942 \\
\hline PREQ3 - POSTQ3 & .121 & .819 & .020 & .222 & 2.364 & 255 & .0188 \\
\hline PREQ4 - POSTQ4 & -.223 & .979 & -.343 & -.102 & -3.640 & 255 & $.0003 *$ \\
\hline PREQ5 - POSTQ5 & .207 & .817 & .107 & .308 & 4.057 & 255 & $.0000 *$ \\
\hline PREQ6 - POSTQ6 & .094 & 1.009 & -.030 & .219 & 1.492 & 253 & .1369 \\
\hline PREQ7 - POSTQ7 & .149 & 1.326 & -.014 & .313 & 1.795 & 254 & .0738 \\
\hline PREQ8 - POSTQ8 & -.181 & 1.013 & -.306 & -.056 & -2.849 & 253 & .0047 \\
\hline PREQ9 - POSTQ9 & -.083 & 1.150 & -.225 & .059 & -1.148 & 252 & .2520 \\
\hline PREQ10 - POSTQ10 & .063 & .841 & -.041 & .167 & 1.194 & 253 & .2338 \\
\hline PREQ11 - POSTQ11 & -.122 & 1.004 & -.246 & .002 & -1.937 & 253 & .0539 \\
\hline PREQ12 - POSTQ12 & .031 & .902 & -.080 & .143 & .557 & 253 & .5783 \\
\hline PREQ13 - POSTQ13 & 202 & .921 & .088 & .317 & 3.490 & 251 & $.0005^{*}$ \\
\hline PREQ14 - POSTQ14 & .142 & .932 & .027 & .258 & 2.429 & 252 & .0159 \\
\hline PREQ15 - POSTQ15 & 185 & 1.067 & .053 & .317 & 2.763 & 253 & .0062 \\
\hline PREQ16 - POSTQ16 & -.126 & 1.050 & -.257 & .004 & -1.916 & 252 & .0565 \\
\hline PREQ17 - POSTQ17 & .075 & .919 & -.039 & .188 & 1.298 & 253 & .1956 \\
\hline PREQ18 - POSTQ18 & 295 & 1.019 & .169 & .421 & 4.617 & 253 & $.0000 *$ \\
\hline PREQ19 - POSTQ19 & .024 & 1.078 & -.110 & .157 & .349 & 253 & .7271 \\
\hline PREQ20 - POSTQ20 & -.220 & 1.055 & -.351 & -.090 & -3.330 & 253 & $.0010 *$ \\
\hline PREQ21 - POSTQ21 & .142 & 1.000 & .018 & .265 & 2.259 & 253 & .0247 \\
\hline PREQ22 - POSTQ22 & .056 & .796 & -.043 & .154 & 1.107 & 251 & .2692 \\
\hline PREQ23 - POSTQ23 & .155 & 1.066 & .023 & .287 & 2.306 & 251 & .0219 \\
\hline PREQ24 - POSTQ24 & -.091 & 1.021 & -.217 & .036 & -1.416 & 252 & .1581 \\
\hline
\end{tabular}




\begin{tabular}{|c|c|c|c|c|c|c|c|}
\hline PREQ25 - POSTQ25 & .143 & .877 & .034 & .252 & 2.587 & 251 & .0102 \\
\hline PREQ26 - POSTQ26 & .300 & .958 & .182 & 419 & 4.989 & 252 & $.0000 *$ \\
\hline PREQ27 - POSTQ27 & .210 & .803 & .111 & .310 & 4.158 & 251 & $.0000 *$ \\
\hline PREQ28 - POSTQ28 & .151 & .849 & .046 & 257 & 2.825 & 250 & .0051 \\
\hline PREQ29 - POSTQ29 & .538 & 1.066 & .405 & .672 & 7.941 & 246 & $.0000 *$ \\
\hline PREQ30 - POSTQ30 & .170 & .917 & .055 & .285 & 2.914 & 246 & .0039 \\
\hline PREQ31 - POSTQ31 & -.104 & .815 & -.205 & -.003 & -2.018 & 249 & .0446 \\
\hline PREQ32 - POSTQ32 & -.204 & .788 & -.302 & -.106 & -4.094 & 249 & $.0001 *$ \\
\hline PREQ33 - POSTQ33 & -.280 & .958 & -.399 & -.161 & -4.623 & 249 & $.0000 *$ \\
\hline PREQ34 - POSTQ34 & -.096 & .850 & -.202 & .010 & -1.787 & 249 & .0752 \\
\hline PREQ35 - POSTQ35 & -.012 & .765 & -.107 & .083 & -.249 & 248 & .8038 \\
\hline PREQ36 - POSTQ36 & -.092 & .854 & -.199 & .014 & -1.707 & 248 & .0891 \\
\hline PREQ37 - POSTQ37 & .157 & 1.141 & .014 & 299 & 2.166 & 248 & .0313 \\
\hline PREQ38 - POSTQ38 & .036 & .796 & -.063 & .136 & .718 & 247 & .4737 \\
\hline PREQ39 - POSTQ39 & -.149 & .958 & -.268 & -.029 & -2.448 & 248 & .0151 \\
\hline PREQ40 - POSTQ40 & -.069 & .877 & -.178 & .041 & -1.231 & 247 & .2194 \\
\hline PREQ41 - POSTQ41 & -.286 & 1.089 & -.422 & -.150 & -4.142 & 247 & $.0000 *$ \\
\hline PREQ42 - POSTQ42 & .097 & .794 & -.003 & .196 & 1.920 & 247 & .0561 \\
\hline PREQ43 - POSTQ43 & -.170 & .989 & -.294 & -.046 & -2.701 & 246 & .0074 \\
\hline PREQ44 - POSTQ44 & .032 & .892 & -.079 & .144 & .571 & 246 & .5688 \\
\hline PREQ45 - POSTQ45 & -.167 & 1.184 & -.316 & -.018 & -2.212 & 244 & .0279 \\
\hline PREQ46 - POSTQ46 & .211 & 1.010 & .084 & .337 & 3.275 & 246 & .0012 \\
\hline PREQ47 - POSTQ47 & .049 & .840 & -.057 & .154 & .909 & 246 & .3640 \\
\hline PREQ48 - POSTQ48 & -.053 & .792 & -.152 & .047 & -1.044 & 246 & .2973 \\
\hline PREQ49 - POSTQ49 & .077 & .893 & -.035 & .189 & 1.356 & 245 & .1763 \\
\hline PREQ50 - POSTQ50 & .045 & 1.113 & -.095 & .184 & .629 & 246 & .5299 \\
\hline
\end{tabular}


Appendix B: Key Categories in Participant Summary

\begin{tabular}{|c|c|c|}
\hline Main category & Mid-level category & Sub-codes (examples/not exhaustive) \\
\hline \multirow[t]{7}{*}{ Basic demographics } & \multirow[t]{2}{*}{ State residency (SR) } & SR-In-state \\
\hline & & SR-Out of state \\
\hline & \multirow[t]{2}{*}{ Family SES (FS) } & FS-Middle class \\
\hline & & FS-Working class \\
\hline & \multirow[t]{3}{*}{ Connection to engineers (CTE) } & CTE-Parents \\
\hline & & CTE-Relatives \\
\hline & & CTE-Acquaintance \\
\hline \multirow[t]{9}{*}{ High school \& personality } & \multirow[t]{3}{*}{ Type of high school (HS) } & HS-Rural \\
\hline & & HS-Suburban \\
\hline & & HS-Urban/City \\
\hline & \multirow{3}{*}{$\begin{array}{l}\text { Type of student in high school } \\
\text { (TSHS) }\end{array}$} & TSHS-Top students \\
\hline & & TSHS-High-middle \\
\hline & & TSHS-Middle \\
\hline & \multirow[t]{3}{*}{ Personality } & Personality-Social/Active \\
\hline & & Personality-Introvert \\
\hline & & Personality-Goal-oriented \\
\hline \multirow[t]{16}{*}{ Campus experience } & \multirow[t]{9}{*}{ Hardest challenge } & Challenge-Heavy workload \\
\hline & & Challenge-Time management \\
\hline & & Challenge-Finding balance \\
\hline & & Challenge-Hard subject content itself \\
\hline & & Challenge-Overall adjustment \\
\hline & & Challenge-Social relationship \\
\hline & & Challenge-Working in a group \\
\hline & & Challenge-Engineering class \\
\hline & & Challenge-Chemistry class \\
\hline & \multirow[t]{7}{*}{ Support system } & Support-Friends \\
\hline & & Support-College instructor \\
\hline & & Support-Parents \\
\hline & & Support-High school teachers \\
\hline & & Support-Relatives \\
\hline & & $\begin{array}{l}\text { Support-Professional learning community } \\
\text { (PLC) }\end{array}$ \\
\hline & & Support-Other adults \\
\hline \multirow[t]{12}{*}{ ENGR 1201 class experience } & \multirow[t]{7}{*}{ Negative aspects of ENGR 1201} & ENGR01-Negative-Online quiz \\
\hline & & ENGR01-Negative-Busy work \\
\hline & & ENGR01-Negative-Moodle problem \\
\hline & & ENGR01-Negative-Lecture session \\
\hline & & $\begin{array}{l}\text { ENGR01-Negative-Inconsistency btw } \\
\text { lecture/lab }\end{array}$ \\
\hline & & ENGR01-Negative-Group project itself \\
\hline & & ENGR01_Negative-Group work process \\
\hline & \multirow{5}{*}{ Positive aspects of ENGR 1201} & ENGR01-Positive-Group project itself \\
\hline & & ENGR01-Positive-TA \\
\hline & & ENGR01-Positive-Instructor \\
\hline & & ENGR01-Positive-Class structure \\
\hline & & ENGR01-Positive-Course content \\
\hline
\end{tabular}

